\title{
A case of kwashiorkor in a child with congenital hypothyroidism
}

\author{
Helena Aneke Tangkilisan, Teguh Wijayanto, Sugianto Wiriadinata \\ Department of Child Health, Faculty of Medicine Sam Ratulangi University Manado, Indonesia
}

\begin{abstract}
A 12-year-old Indonesian girl with the body weight of $9.8 \mathrm{~kg}$ and length $78 \mathrm{~cm}$ was admitted to the Department of Child Health, Manado General Hospital with kwashiorkor and congenital hypothyroidism. The main complaint was edema starting 3 weeks before admission. Physical examination showed body weight for age (BW/A) $14.3 \%$, body weight for body length (BW/BL) $66.0 \%$ and body length for age (BL/A) 49.1\%. On admission she looked severely ill, apathetic, with hypothermia and hypotonia. Almost all signs and symptoms of kwashiorkor and congenital hypothyroidism were found accompanied bronchopneumonia and dermatologic problems. Laboratory findings showed severe anemia, leukocytosis, hypoproteinemia, hyponatremia, hypokalemia, elevated thyroid stimulating hormone and low level of Thyroxine-4. Bone age equaled to a newborn baby bone age. There was no thyroid tissue on thyroid ultrasound examination. The patient was treated for severe protein energy malnutrition and Thyrax ${ }^{R}$. Problems of kwashiorkor could been solved well but not with the congenital hypothyroidism. She was discharged from hospital after 2 months treatment and till now at $14^{\text {th }}$ year of age with her developmental milestones equals to that of 8 month old baby. [Paediatr Indones 2001;41:305-307]
\end{abstract}

Keywords: congenital hypothyroidism, kwashiorkor, delay in diagnosis

THE DESCRIPTION OF KWASHIORKOR GIVEN BY WILLIAMS IN her first published article almost 70 years ago (1933) is accurate up till now, although she did not introduce the name of kwashiorkor until her paper in $1935 .{ }^{1}$ Kwashiorkor as one form of severe protein energy malnutrition (PEM) is clinically differentiated from marasmus as another form of severe PEM according to the existence of predominate edema in kwashiorkor. ${ }^{1,2}$ Although the prevalence of severe PEM in Indonesia is only about $5 \%$, without adequate treatment and prevention, it will increase the morbidity and mortality rate. ${ }^{2}$

Congenital hypothyroidism $(\mathrm{CH})$ is a clinical syndrome caused by thyroid hormone deficiency. The prevalence of $\mathrm{CH}$ is 1 in 4000 births. The etiologies

Correspondence: Helena Aneke Tangkilisan, MD, Department of Child Health, Faculty of Medicine Sam Ratulangi University Manado, Indonesia. include thyroid dysgenesis, dyshormonogenesis, hypothalamic-pituitary deficiency or transient hypothyroidism. Besides clinical finding and bone survey, the diagnosis of $\mathrm{CH}$ is confirmed by plasma or serum measurement of thyroxin-4 (T-4) and thyroid stimulating hormone (TSH) concentration. All infants with abnormal test results should undergo radionuclide scanning or thyroid ultrasound. Early diagnosis and treatment will prevent the child from mental retardation and physical developmental disturbance. That's why newborn screening for $\mathrm{CH}$ is very important. ${ }^{3.5}$ This case is interesting because both of the diseases occurred concomitantly in one child.

\section{Case Report}

A 12 year-old Minahasan girl, residing in Manado city, was admitted to the Department of Child Health, Manado Central General Hospital on 12 ${ }^{\text {th }}$ July, 1999 
with the main complaint of edema of the whole body. She had never suffered from the same symptom. She was the youngest of 4 siblings, born spontaneously aided by a midwife. Her mother's pregnancy was longer than the previous ones. When she was a baby, according to her mother, there were large protuded tongue, hoarse cry, distended abdomen, protuded ombilicus, prolonged jaundice, skin mottling, inactivity, and hypotonia. The bowel movement was only once in 5-10 days. Her mental and motoric developments were retarded that she could only lie supine. Some of those symptoms existed till she was admitted to the hospital. There were no similar symptoms in her family and they were apparently healthy.

On admission, the physical examination revealed that she looked severely ill, anemic, and apathetic. There was anasarca edema with pitting type; her body weight was $9.8 \mathrm{~kg}$ (equal to $6.8 \mathrm{~kg}$ after it was corrected by $30 \%$ ), body height was $78 \mathrm{~cm}$, head circumference was $47 \mathrm{~cm}$; pulse rate was 72 times per minute; respiratory rate was 24 times per minute; systolic blood pressure was $90 \mathrm{mmHg}$ and diastolic blood pressure was $60 \mathrm{mmHg}$; and body temperature was $36^{\circ} \mathrm{C}$. The skin was so coarse and dry that skin mottling and frog skin were found. She had puffy eyes, sparse hair, shallow nose, opened mouth with macroglossia, and head lag. There were short neck and fingers, retraction of the chest and rales in auscultation, and navel protruding. The abdomen was convex with ascites and enlargement of liver. The extremities were cold.

Laboratory findings showed $\mathrm{Hb} 3.7 \mathrm{~g} / \mathrm{dL}$; leukocyte count $17.900 / \mathrm{ml}$, differential count of segment $78 \%$, lymphocyte $19 \%$ and monocyte $3 \%$, platelet count $292.000 / \mathrm{ml}$, blood sediment rate $26 \mathrm{~mm} / \mathrm{h}$, total protein $3.6 \mathrm{~g} / \mathrm{dL}$, albumin $1.8 \mathrm{~g} / \mathrm{dL}$, cholesterol $108 \mathrm{~g} / \mathrm{dL}$, urea $20.9 \mathrm{mg} / \mathrm{dL}$, creatinine $0.49 \mathrm{mg} / \mathrm{dL}$, $\mathrm{Na} 132 \mathrm{mMol} / \mathrm{L}, \mathrm{K} 3.11 \mathrm{mMol} / \mathrm{L}$, TSH > $75 \mathrm{mU} / \mathrm{ml}$, $\mathrm{T}-4<0.20 \mathrm{ng} / \mathrm{dl}$, fast acid bacilli from gastric aspirates and contact person was negative. Chest $\mathrm{x}$-ray showed severe bronchopneumonia. Bone age survey equaled to that of newborn baby. We couldn't find thyroid tissue in ultrasound examination.

The patient was treated with 10 steps management of severe PEM which is recommended by Indonesian Ministry of Health, and Thyrax ${ }^{\mathrm{R}}$. She was discharged with better condition. Kwashiorkor problem could be solved completely, but prognosis of $\mathrm{CH}$ was bad. She came to control her health and receive recipe of Thyrax ${ }^{R}$ every month. Her activity, body weight and height increased but her mental development was the same. Two years later, at the age of 14 years, her height was increased 24 $\mathrm{cm}$, from $78 \mathrm{~cm}$ to $102 \mathrm{~cm}$, but her capabilities were not different from those of 8 months baby so she still need assistance for her life, making her quality of life very poor.

\section{Discussion}

According to Ministry of Health, a patient is called severe $\mathrm{PEM}$ if $\mathrm{BW} / \mathrm{A}<60 \%$ or $\mathrm{BW} / \mathrm{H}<70 \%$ to median standard of WHO-NCHS. The presence of anasarca edema in severe PEM refers to kwashiorkor. $^{1,2}$ In this case BW/A was $14.3 \%$ and $\mathrm{BW} / \mathrm{H}$ was $66 \%$. The management of this case was based on 10 steps approach of severe PEM, i.e, to treat and to prevent hypoglycemia, hypothermia, dehydration, electrolyte imbalance, infection, to begin nutrition care, to correct micronutrient deficiency, to facilitate catch up growth, sensory stimulation and emotional support, and to prepare and plan follow up after recovery. Children with severe PEM is discharged from hospital if the BW/ A reaches $80 \%$ or $\mathrm{BW} / \mathrm{H}$ reaches $70 \%$ to $\mathrm{WHO}$ $\mathrm{NCHS}$ and there is no other serious problem. Our patient was discharged with BW $9.5 \mathrm{~kg}$ (without edema) and $\mathrm{H} 79 \mathrm{~cm}(\mathrm{BW} / \mathrm{H} 89.6 \%$ to WHO. $\mathrm{NCHS}), \mathrm{Hb} 9.4 \mathrm{~g} / \mathrm{dL}$, leukocytes $7.800 / \mathrm{ml}^{3}$, total protein $7.49 \mathrm{~g} / \mathrm{dL}$. The interesting point in the kwashiorkor management of this patients was the slow response to standard therapy before the diagnosis of $\mathrm{CH}$ and Thyrax $^{\mathrm{R}}$ therapy.

Neuwman et al in their study found the increasing incidence of pyoderma, dermatomycosis, UTI, stomatitis, pneumonia and TB in the severe PEM group was different from that in the moderate PEM and control group significantly. They conclude that severe PEM group is very prone to infection caused by many pathogens. ${ }^{6}$ Although characteristic signs of $\mathrm{CH}$ in our patient were found almost completely, the diagnosis and treatment of this disease could not be made earlier, because cases like this were very rare. Based on the neonatal history and crossexamined to physical finding when she admitted to the hospital, we made scoring system referred to Neonatal Thyroid Index. If the total score reaches 4, 
suspicion to $\mathrm{CH}$ can be made. The total score in this patient was 6 .

The delayed finding and therapy of specific $\mathrm{CH}$ in this patient cannot avoid the child from mental retardation and physical developmental disturbance. A child with $\mathrm{CH}$ treated at the age less than 3 years will reach mean IQ of 89 , at the age of 3-6 years will reach mean IQ of 70, while if he/she is treated at 7 years old the mean IQ will $54 .^{?}$

\section{References}

1. Waterlow JC. Protein energy malnutrition; New ed. London: 1992;1-13.
2. Depkes RI. Pedoman tatalaksana kekurangan energi protein pada anak di rumah sakit kabupaten / kodya. Jakarta: Departemen Kesehatan RI; 2000.

3. Toft AD. Thyroxine therapy. N Engl J Med 1994;331:174-80.

4. Fisher DA. Management of congenital hypothyroidism. J Clin Endocrinol Metab 1991;72: 523-9.

5. Kaniawati M. Pemeriksaan TSH generasi ketiga. Informasi Laboratorium Prodia 1994;2:3-4.

6. Neumann CG, Lawlor GJ, Stiehm ER, Swenseid $\mathrm{ME}$, Newton C, Herbert J, et al. Imunologic responses in malnourished children. Am J Clin Nutr 1975;28:89. 104.

7. LaFranchi SH. Hypothyroidism, congenital and acquired. In: Kaplan SA, ed. Clinical pediatrics and adolescent endocrinology. Philadelphia; 1982. p. 82-95. 